Datokarama English Education Journal Vol.2 No. 2, 2021

\title{
THE USE OF PODCAST MEDIA IN LITERAL LISTENING SUBJECT TO SECOND SEMESTER STUDENTS OF ENGLISH TADRIS STUDY PROGRAM 2020/2021 AT IAIN PALU
}

\author{
Nurhikmah \\ Muhammad Ihsan \\ Afifah \\ Dzakiah \\ Study Program of English Tadris Faculty of Tarbiyah and Teacher Training \\ State Islamic University (UIN) Datokarama Palu \\ E-mail: misshikmah@yahoo.com
}

\begin{abstract}
This paper focuses on the use and response of students related to podcast media in literal listening subject to second semester students of the English Tadris Study Program at State Institute for Islamic Studies (IAIN) Palu. The author applies a qualitative research design. The method used in this research is interview and literature study, the results of the study show that the use and response of students regarding podcast media is good, this is evidenced by the results of interviews conducted by researchers with students who are taught using podcast media and lecturers who present material using podcast media.
\end{abstract}

Keywords: Use, Podcast, Literal Listening. 
Datokarama English Education Journal Vol.2 No. 2, 2021

\section{Background}

English is the most important language used in almost every aspect of life around the world such as business, industry, nursing, finance, and especially education. For this reason, people in the world need to master English. However, mastering English requires some basic knowledge. In the current era of modernization, the generation that currently dominates in Indonesia is students with the main characteristic of knowing digital technology.

The use of learning media in education is very important. This is based on the benefits or uses of the media. Learning media is anything that stimulates the thoughts, feelings, attention, and abilities or skills of students to encourage the learning process. The existing learning media requires development to be more easily accessed, used, and understood by students. ${ }^{1}$ A podcast is an acronym for iPod Broadcasting which refers to the Apple iPod as the first podcast distribution platform introduced by Steve Jobs. ${ }^{2}$ In Indonesia, podcast makers or so-called podcasters are still very few. In simple terms according to Bonini, podcasts are defined as the technology used to distribute, receive, and listen to on-demand content produced by professional and amateur radio. ${ }^{3}$

These audio files can be accessed directly from a desktop, device or sent to a portable media device such as an MP3 player for listening "on the go". Several

\footnotetext{
${ }^{1}$ Dewi Mayangsari and Dinda Rizki Tiara, "Podcast Sebagai Media Pembelajaran Di Era Milenial," Jurnal Golden Age Universitas Hamzanwadi 3, no. 02 (2019): 126.

${ }^{2}$ Cut Medika Zellatifanny, "Tren Diseminasi Konten Audio on Demand Melalui Podcast : Sebuah Peluang dan Tantangan di Indonesia," Journal Pekommas 5, no. 2 (2020): 117.

${ }^{3}$ Ibid, hlm. 138.
}

things can be used in using podcasts to learn English, including as an effective medium to train and improve speaking, listening, writing, and reading skills in English. Now podcasts are here which have experienced developments from various aspects, such as technology, content, and other opportunities. Even though it has only been a year since the podcast started, the growth in enthusiasts is quite significant.

This is evidenced by the Daily Social survey in 2018 of 2023 smartphone users who state that $68 \%$ of respondents are quite familiar with the existence of podcasts and $80 \%$ of them have listened to podcasts in the last 6 months. These results are a good starting point for podcasts to continue to grow audio/audiovisual a digital-based. ${ }^{4}$ The concept of this podcast can be said to be similar to an audio blog, usually, one podcast channel has a common theme in the discussion, for example about education, business, technology, and so on, and each channel has episodes with certain titles that will be discussed. In each episode, listeners can choose to listen to/watch the shows they like and can skip the ones they do not like.

This podcast can be done streaming or downloaded, and we can listen to it offline anytime. As a mass-consumed technology, podcasts are expected to help students with various kinds of information, especially in terms of education and learning English. ${ }^{5} \mathrm{As}$ stated by Abdulrahman in his research that students or learners have a positive response

\footnotetext{
${ }^{4}$ brahim Adnan Dan Dudi Iskandar, "STUDI NETNOGRAFI BELAJAR MEMBUAT PODCAST PADA KOMUNITAS THE PODCASTERS DI MEDIA SOCIAL DISCORD," Jurnal Syntax Transformation 1, no. 8 (2020): 55. ${ }^{5}$ Norhayati and Sherly Jayanti, "Pemanfaatan Teknologi Untuk Mendukung Kegiatan Belajar Secara Mandiri (Studi Kasus: Penggunaan Podcast Oleh Mahasiswa Di Kota Palangkaraya)," Jurnal Humaniora Teknologi 6, no. 1 (2020): 29-36.
} 


\section{Datokarama English Education Journal Vol.2 No. 2, 2021}

to the use of podcasts during listening comprehension in English lessons. ${ }^{6}$

Students feel that by using podcasts, listening comprehension material becomes more authentic. For listening comprehension skills, it will make teaching and learning activities more enjoyable. This makes them more motivated to learn English. At the higher level of students, for example, students at high school or college, those who already understand technology, can easily access podcasts independently. Besides, the easy use of podcasts allows podcasts to be played anytime and anywhere even by using a simple playing device, such as a computer or smartphone. These students have the freedom to use the technology they have so that if they can make good use of it, it can help them to improve their English skills independently. In connection with the situations and conditions that have been described, the researcher is interested in researching second-semester students who have used podcast media when learning listening courses.

Based on the explanation above, the researcher wants to know in-depth how the use and responses of students by using podcast media on students' English learning is associated with using descriptive qualitative methods. Therefore, this study carries the theme "The use of Podcast media in literal listening subject to second semester students of English tadris program through interviews and literature study".

\section{Literature Review}

\subsection{Podcast as New Media}

The term New Media has been used in the 1960s to cover a diverse and growing set of communication technologies.

${ }^{6}$ Ibid, hal. 30
McQuail in the book Mass Communication Theory explains that new media is a variety of communication technology devices that share the same characteristics and are related to digitalization and its wide availability. ${ }^{7}$ According to Dennis McQuail, the main characteristics of new media are connectedness, wide access to audiences, both as message recipients and senders, interactive, diverse functions and characteristics that can be reached anywhere and anytime. ${ }^{8}$ One of the most important parts that cannot be separated from new media is the internet. The emergence of new media is an effect of the proliferation of internet use and is supported by advances in information technology.

The internet is a supporting technology in the digital media industry as well as a tool to convey messages quickly and widely. With the internet, the need for information can easily be fulfilled. In addition, new media has made conventional media no longer the main choice. People tend to enjoy streaming services that are considered more accessible at the desired time. The development of new media is marked by the presence of podcasts which are currently being loved by the public. Podcasts are becoming a new medium in the Indonesian broadcasting world, especially in audio content. ${ }^{9}$ In the digital era, podcasts have become a means of providing interesting audio-based content and have a long duration compared to radio. The role of

\footnotetext{
${ }^{7}$ Fadilah, Yudhapramesti, and Aristi, "Podcast Sebagai Alternatif Distribusi Konten Audio."

${ }^{8}$ Iskandar Dinata Ramadhany, "peran podcast sebagai mediapenyiaran modern berbasis audio (Studi Kualitatif Pengguna Memilih Podcast Sebagai Media Alternatif Hiburan) Iskandar," Universitas Islam Kalimantan Muhammad Arsyad Al-Banjari, no. 1 (2020): 1-8,

${ }^{9}$ Teni Nurrita, "Pengembangan Media Pembelajaran Untuk Meningkatkan Hasil Belajar Siswa" 3, no. 1 (2018): 171-187.
} 
Datokarama English Education Journal Vol.2 No. 2, 2021

podcasts as new media is not to replace radio, but to provide an alternative option to turn on audio content that was dimmed. Even though it only presents an audio format in its use, it turns out that podcasts still have a place for some people who prefer to listen.

Based on the characteristics of new media described by McQuail above, podcast can be said to be a new media product. The reason is, its on-demand nature where the audience can decide for themselves the time and topic they want to make podcasts a very flexible medium. The emergence of various platforms that provide a comment column feature also makes podcasts an interactive medium and allows for wide interaction. In addition, the "uploading" service makes easier for the audience to access because there is no need to rely on streaming, which requires a large internet quota.

\subsection{Definition of Listening}

Listening is an active process in which listeners select and interpret information which comes from auditory and visual clues to define what is going on and what the speakers are trying to express. ${ }^{10}$ Active means that the listener is doing more than simply decoding what is heard. Listeners get information (from visual and auditory clues) and relate this information to what they already know. The process of listening performance is the invisible and inaudible process of recognizing meaning from the auditory signals being transmitted to the ear and brain. ${ }^{11}$ Recognizing the spoken words in listening is a challenging

${ }^{10}$ Michael Rost, Teaching English to Speakers of Other Language (Cambridge University Press. 2001),3

${ }^{11} \mathrm{H}$. Dounglas Brown, Language Assesment: Principle and Classroom Practices (England: Longman, 2004)118 task for most language learners. ${ }^{12}$ It is because learners have limited control over the rate of input, unlike reading where learners can read more slowly or even reread the whole passages. Segmenting the natural flow of continuous speech into the individual word is not an easy task, because, in contrast to written discourse, spoken language does not have clear word boundaries. In spoken discourse, the words are blended into a speech, so if someone does not know a language, it is very difficult to pick out the individual words.'

\subsection{The Use of Podcasts in English Language Teaching}

"Podcasting" involves placing material that is recorded on a website, and can be downloaded and listened to at a later time. Although originally developed as a way to provide access to recorded music by downloading, for a fee, from the Internet, podcasting is now widely used by radio and television stations to make interviews or other interesting material available to listeners. ${ }^{13}$ Podcasts can be downloaded to portable MP3 devices, for example, Apple iPods and played back either through earphones or speakers. The difference between podcasting and uploading regular audio recordings in learning is that Podcasting can be said to involve editing and indexing the recorded, or uploading specially designed audio clips, whereas plain audio is a simple raw audio recording that records anyone. ${ }^{14}$ Podcasting has been

\footnotetext{
${ }^{12}$ Ibid, 53

${ }^{13}$ RN Margaret M. Hansen EdD, MSN, "Podcasting and MP3 Players: Emerging Education Technologies," Nursing and Health Professions Faculty Research and Publications 24, no. 1 (2006): 9-13.

${ }^{14}$ Zeynel Cebeci and Mehmet Tekdal, "Using Podcasts as Audio Learning Objects," Interdisciplinary Journal of Knowledge and Learning Objects 2 (2006): 047-057.
} 
Datokarama English Education Journal Vol.2 No. 2, 2021

used by educators as a medium of learning in schools and universities. ${ }^{15}$ Providing material using podcast media can be in audio or audiovisual form.

Podcasts are serial digital video and audio broadcasts that can be downloaded and played on mobile devices. The term "Podcast" comes from two technologies, "iPod" and "Broadcast". Podcasts are the same as radio but there is a fine line between radio and Podcasts. Podcasts give listeners full access to select their favorite program according to their convenience and listen to it. Podcasts were first recognized in 2004, and they are defined as internet audio blogs or internet audio publishing. Audio recordings are designed to be downloaded and listened to on a portable mp3 player or on a computer. Podcasts are sent online automatically via a website, so they are different from other audio. Podcasts make use of sound which is the most powerful tool that gets in touch with the audience very quickly. Thus, a podcast is a series of sound files that comprise comprehensive educational information to make users an advanced learner. Sloan defines Podcasting as one of the innovative means of broadcasting over the internet and it can also be used to transfer digital audio content automatically to cell phones. ${ }^{16}$ Gromik claims that podcasting provides students with "full access to authentic resources" in non-English speaking contexts. Additionally, Podcasts offer a 'real-life listening' resource that all is tuners can

\footnotetext{
${ }^{15}$ Mark J.W. Lee and Anthony Chan, "Reducing the Effects of Isolation and Promoting Inclusivity for Distance Learners through Podcasting," Turkish Online Journal of Distance Education 8, no. 1 (2007): 85-104.

${ }^{16} \mathrm{P}$. Constantine, "Podcasts: Another Source for Listening Input," The Internet TESL Journal. 13 (1). (2007).
}

benefit from foreign language. ${ }^{17}$ Constantine explains the importance of using Podcasts in foreign language classes from beginner level to advanced. ${ }^{18}$ Beginners can benefit from general listening and learning a new language. For the intermediate level, students can access authentic material and are exposed to various voices while for the advanced level, they can choose podcast material based on their own needs. Another benefit of the podcast has been proven by Lu through his four week study. This study investigates how podcasts in English, Great Britain and the US can improve the listening and speaking proficiency of language learners in an EFL context involving Taiwanese students who have never previously known native English. Participants were asked to transcribe the podcast, identify vocabulary and grammar in context, and discussion of the topic took place in English at the end of each week. The study revealed that using podcasts in listening instruction in this way had a positive impact and that participants gained confidence in their ability to understand English as a whole. Specifically in teaching listening comprehension, Podcasts are also used as the primary resource and review tool in EFL classes. ${ }^{19}$ A study conducted by Ashraf, Naroozi and Salami showed that podcasts had a significant impact on the listening comprehension of both EFL Iranian students. ${ }^{20}$ Researcher Hawke's reported a significant improvement in science students' scientific English listening skills via podcast. As supplementary

\footnotetext{
${ }^{17}$ Nicolas Gromik, "EFL Learner Use of Podcasting Resources: A Pilot Study," JALT CALL Journal, 4(2), p. 47-60 (2008).

${ }^{18}$ Ibid.

${ }^{19}$ Vicenc Fernandez, Jose M Sallan, and Pep Simo, "Past, Present, and Future of Podcasting in Higher Education," Universitat Politècnica de Catalunya, Barcelona, Spain, no. April 2016 (2015): 305-330.

${ }^{20}$ Ibid, hlm 325
} 
Datokarama English Education Journal Vol.2 No. 2, 2021

material, podcasts help students pay attention to their content and motivate them to learn to listen using both bottom up and top down strategies. ${ }^{21}$ Apart from that, Istanto has also proven that Podcasts improve students' listening skills and grammar knowledge. ${ }^{22}$ Not only for Listening comprehension skills, several studies have also shown a significant effect of podcasts on students' vocabulary, pronunciation, speaking, grammar, and writing skills. Several studies have also proven that podcasts are a very useful and easy to download resource that provides authentic material to students so that they can expand their knowledge and enable them to practice listening. ${ }^{23}$

Kavaliuskine \& Anusiene showed that students have positive feedback on podcasts, which is shown by their high appreciation of the use of podcasts in English classrooms and their extensive use of podcasts in listening practice. ${ }^{24}$ In addition, students' enthusiasm in using podcasts as a learning resource is shown by their efforts to frequently download podcasts, listen to them regularly, such as for listening practice and entertainment, Several studies have also concluded that podcasts increase student motivation due to a variety of topics.

\footnotetext{
${ }^{21}$ Philip Hawke, "Using Podcasts in Independent Listening Courses: Legal and Pedagogical Implications," The JALT CALL Journal 6, no. 3 (2010): 219-234.

22Johanna Wulansari Istanto and Indrianti, "Pelangi Bahasa Indonesia Podcast: What, Why and How?," Electronic Journal of Foreign Language Teaching 8, no. January 2009 (2011): 371-384.

${ }^{23}$ Ibid, hlm. 364

${ }^{24}$ Galina Kavaliauskiene, "Podcasting: A Tool for Improving Listening Skills," The Journal of Teaching English with Technology (TEwT) 8, no. 4 (2008): 1-17, http://www.tewtjournal.org/VOL\%5Cn8/ISSUE\%5C n4/A\%5CnWORD\%5CnFROM\%5CnA\%5CnTECHI E.pdf.
}

\subsection{Podcasting Process}

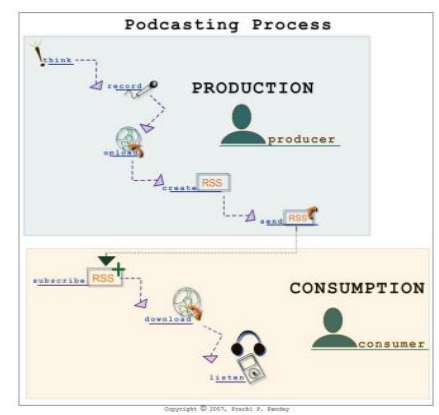

Source: Prachi Parashar

Panday Simplifying

Podcasting

In this case, the lecturer who brings literal listening material using podcast media will only act as consumption which will only download the audio about learning that will be delivered on certain podcast channels through the Spotify application, then distributed as teaching material for students.

\section{Methodology}

In this research, the researcher applied a qualitative approach questions includes data obtained from interviews at Teacher Training and Tarbiyah Faculty, especially English Tadris students (TBI). The researcher also interviewed second-semester students who studied literal listening courses and used podcast media in learning. The researcher conducted interviews when students took literal listening learning in online classes. In this case, the researcher conducted online interviews, online in the form of personal chat, video call, voice notes, and documentation with the students by using WhatsApp application. The number of English Tadris Study Program classes 2020/2021 consisted of three classes, namely TBI-1, TBI-2, and TBI-3, in which each class had a different number of students. TBI- 1 numbered 22 people, TBI- 2 numbered 23 people and TBI-3 numbered 22 people, so the total number of students in the second-semester majoring English 
Datokarama English Education Journal Vol.2 No. 2, 2021

Tadris was 67 people. The researcher conducted interviews with the number of respondents one-third of the total number of students, namely 23 people, who were active and were studying the literal listening course. The researcher interviewed lecturers who presented literal listening courses, especially those who used podcast media in their teaching. supporting data obtained through written sources. This written source can be obtained through books, scientific journals, and others with topics that are relevant and related to research.

\section{Result and Discussion}

In this section, the author describes and discusses the results of this study. The research was conducted in the midst of the corona pandemic and students did not carry out the learning process on campus effectively, in other words, they did online learning from home. Where every student who will be interviewed will be contacted by the researcher using the WhatsApp application and make video calls with the students who will be interviewed. Interviews were conducted once a week after each literal listening lesson was completed, the researchers interviewed 4 students each week in TBI-1 and TBI-2 classes in turn. This aims to see how the responses related to the use of podcast media in literal listening learning are. research results show that the use of podcast media in literal listening subjects is very helpful in learning, especially for students majoring in the English Tadris Program. Podcasts are serial digital video and audio broadcasts that can be downloaded and played on mobile devices. In using podcast media, it is quite easy to access.

\section{Conclusion and Suggestions}

\subsection{Conclusion}

The use of podcast media to students of the
English Tadris Study Program of IAIN Palu got a good response in learning literal listening. Media podcasts are very effective in learning literal listening, especially to improve students' listening skills as students in English language courses. This media is a form of technological progress that we can take advantage of in the teaching and learning process, in this case an internet connection plays an important role in the use of this media. The use of podcast media makes students think more critically in analyzing an audio.

\subsection{Suggestion}

The researcher recommends that students continue to practice their listening skills using podcast media to get used to listening to English audio. In the current digital era, mastering technology will be very helpful in the teaching and learning process. 
Datokarama English Education Journal Vol.2 No. 2, 2021

\section{References}

Brown, H. Douglas. Language Assessment: Principle and Classroom Practices. England: Longman, 2004.

Cebeci, Zeynel, and Mehmet Tekdal. "Using Podcasts as Audio Learning Objects." Interdisciplinary Journal of Knowledge and Learning Objects 2 (2006)

Constantine, P. "Podcasts: Another Source for Listening Input." The Internet TESL Journal. 13 (1). (2007).

Fadilah, Efi, Pandan Yudhapramesti, and Nindi Aristi. "Podcast Sebagai Alternatif Distribusi Konten Audio." Jurnal Kajian Jurnalisme 1, no. 1 (2017)

Fernandez, Vicenc, Jose M Sallan, and Pep Simo. "Past, Present, and Future of Podcasting in Higher Education." Universitat Politècnica de Catalunya, Barcelona, Spain, no. April 2016 (2015)

Gromik, Nicolas. "EFL Learner Use of Podcasting Resources: A Pilot Study." JALT CALL Journal, 4(2), p. 47-60 (2008).

Hawke, Philip. "Using Podcasts in Independent Listening Courses: Legal and Pedagogical Implications." The JALT CALL Journal 6, no. 3 (2010)

Ibrahim Adnan Dan Dudi Iskandar. "STUDI NETNOGRAFI BELAJAR MEMBUAT PODCAST PADA KOMUNITAS THE PODCASTERS DI MEDIA SOCIAL DISCORD." Jurnal Syntax Transformation 1, no. 8 (2020)

Iskandar Dinata Ramadhany. "PERAN PODCAST SEBAGAI MEDIA PENYIARAN MODERN BERBASIS
AUDIO (Studi Kualitatif Pengguna Memilih Podcast Sebagai Media Alternatif Hiburan) Iskandar." Universitas Islam Kalimantan Muhammad Arsyad Al-Banjari, no. 1 (2020): 1-8.

Istanto, Johanna Wulansari, and Indrianti. "Pelangi Bahasa Indonesia Podcast: What, Why and How?" Electronic Journal of Foreign Language Teaching 8, no. January 2009 (2011)

Kavaliauskiene, Galina. "Podcasting: A Tool for Improving Listening Skills." The Journal of Teaching English with Technology (TEwT) 8, no. 4 (2008): 117.

http://www.tewtjournal.org/VOL\%5Cn 8/ISSUE\%5Cn4/A\%5CnWORD\%5Cn FROM\%5CnA\%5CnTECHIE.pdf.

Access January 28, 2021

Lee, Mark J.W., and Anthony Chan.

"Reducing the Effects of Isolation and Promoting Inclusivity for Distance Learners through Podcasting." Turkish Online Journal of Distance Education 8, no. 1 (2007)

Mayangsari, Dewi, and Dinda Rizki Tiara. "Podcast Sebagai Media Pembelajaran Di Era Milenial." Jurnal Golden Age Universitas Hamzanwadi 3, no. 02 (2019)

Margaret M. Hansen EdD, MSN, RN. "Podcasting and MP3 Players: Emerging Education Technologies." Nursing and Health Professions Faculty Research and Publications 24, no. 1 (2006)

Norhayati, and Sherly Jayanti. "Pemanfaatan Teknologi Untuk Mendukung Kegiatan Belajar Secara Mandiri (Studi Kasus: 
Datokarama English Education Journal Vol.2 No. 2, 2021

Penggunaan Podcast Oleh Mahasiswa

Di Kota Palangkaraya)." Jurnal

Humaniora Teknologi 6, no. 1 (2020)

Rost, Michael. Teaching English to

Speakers of Other Language.

Cambridge: Cambridge University

Press, 2001.

Teni Nurrita. "Pengembangan Media

Pembelajaran Untuk Meningkatkan

Hasil Belajar Siswa" 3, no. 1 (2018)

Zellatifanny, Cut Medika. “Tren Diseminasi

Konten Audio on Demand Melalui

Podcast : Sebuah Peluang Dan

Tantangan Di Indonesia." Journal

Pekommas 5, no. 2 (2020) 